\title{
The Effect of Practicing Domestic vs. Foreign Newspaper on Iranian Intermediate EFL Learners' Reading Comprehension Ability
}

\section{Mahboubeh Gholamipour ${ }^{1}$}

* Correspondence:

M.Gholamipour66@yahoo.com

${ }^{1}$ Department of English Language,

Tonekabon Branch, Islamic Azad

University, Tonekabon, Iran

Received: 4 October 2017

Accepted: 20 December 2017

Published online: 20 June 2018

\begin{abstract}
The present study investigated the effect of practicing domestic vs. foreign newspaper on Iranian Intermediate EFL Learners' reading comprehension ability. The main question this study tried to answer was whether or not practicing domestic vs. foreign newspaper has any effect on Iranian Intermediate EFL Learners' reading comprehension ability. To answer this question, 45 Iranian learners were selected via administering an OPT test with the criteria of at least 1 standard deviation below and above the mean of the Oral Proficiency Test (OPT). Reading section of Reading Practice Test was used as the OPT. It consists of 19 items. It takes approximately 25 minutes to complete the reading test. Learners were studying in three intermediate classes in Simin Institute of Ramsar, Iran. The participants were all female and ranged in age from 17 to 19. They were divided into three groups of $15(\mathrm{~N}=15)$ : two experimental groups and a control group. A pretest of reading comprehension was administered to the three groups. The first experimental group was treated by teaching reading comprehension plus domestic newspaper; the second experimental group was treated by teaching reading comprehension plus foreign newspaper and the control group was treated by a placebo. Finally; after 10 sessions, a posttest of reading comprehension was administered to three groups. One-Way ANOVA and Paired Sample were used to analyze the obtained data. The results of OneWay ANOVA and Paired Sample indicated that the participants' practicing domestic vs. foreign newspaper had effect on Iranian Intermediate EFL Learners' reading comprehension ability.
\end{abstract}

Keywords: domestic newspaper, foreign newspaper, EFL learner, mass media, reading comprehension 


\section{Introduction}

English as a foreign language in Iran plays an important role in many aspects of life like education, economy, international relationship, technology, etc. Consequently, the teaching of English became an International enterprise. The widespread need for English as a second or foreign language needs a considerable pressure on the educational resources of many countries. In English, there are four skills: listening, speaking, reading, and writing. The students are expected to have ability in these language skills, which cover receptive and productive language use. Teaching English is not an easy task. English teachers should not only master the language, but they should also be able to make their students learn. Reading, one of the language skills, should be mastered well by the students because it is an essential factor that influences one's activity in communication. Reading is regarded as a decoding skill; that is, interpreting codes into ideas. People consider reading as an important activity so that they usually say that reading is the window of the world. By reading, people can get the information widely without going anywhere (Davies, 1995; Wallace, 1992; Williams, 1996).

According to Adams (1990), reading is one of the main pathways to learn about vocational areas as well as academic areas (e.g., math, language art, science, etc). According to Anderson (1999), with strengthened reading skills, learners will make greater progress and attain greater development in all academic areas. Therefore, reading is necessary to learners' success in their school and finally to their success in life (Salinger, 2003).

Reading is an active process that needs an interaction between the text and the reader that it is essential for successful completion of lifelong and school learning (National Reading Panel, 2000). The aim of reading is comprehension (Salinger, 2003) and reading comprehension is the ability to derive meaning from print and understand the text (NRP, 2000). Therefore, reading can be considered as one of the most important macro-skills in the domain of L2/FL learning and teaching.

As a means of mass education, the press covers some highly valued articles, which can be read by the public to improve their knowledge. The function of educating is served in the form of editorial essay, letter to the editor and all of writing conveying opinions. Besides educating, press also influences the public to do certain things. Newspaper is one kind of printed media, which has been known since a long time ago. It is understandable since newspapers are published in various types according to the need of the society. There are newspapers which specialize in news, hobby, housekeeping, sport, health, and so on. Newspapers are motivating since they offer so many interesting materials to read (Emery, 1968).

\subsection{Statement of the Problem}

Based on the limitation of the study, the researcher formulates the problem of the study as follows: How far does practicing domestic and foreign newspapers have an effect on Iranian Intermediate EFL Learners' reading comprehension ability? 
Based on the findings of studies conducted by some Iranian researchers (Moradi, 1991; Varzegar, 1995), Iranian students are slow readers and don't follow any techniques or procedures to read efficiently. They read word by word and have trouble extracting the essence of the text they are reading. They also translate the words into first language and then try to get the meaning. They revealed that Iranian students don't transfer any reading skill from their first language and they pick up smaller chunks in L2 than L1 reading. So to deal with these problems and help the students to become successful readers, it seems to be a good idea to develop a new technique to help the students become fast readers.

Grabe (1991) points out that the crucial importance of the reading skill in academic contexts had led to considerable research on reading in a second language. Establishing effective instructional frameworks for teaching academic students how to read remains elusive. Despite these problems, Grab (1997) indicates that reading for understanding is a process requiring visual and semantic processing and the construction of summary version of what the text means. Reading to improve pronunciation, practice grammatical forms, and vocabulary does not constitute reading at all because reading involves comprehension (Goodman, 1970) and reading comprehension increases the pleasure and effectiveness of reading. Strong reading comprehension helps in all the other subjects and in the personal and professional lives.

According to Panah (2009), almost 90 percent of students except for those who have attended places like language centers, or they have studied more English courses in addition to their usual school programs and curriculums, are terribly weak in English. If we test for the grammar points, we will surprisingly notice that most of these students have a good knowledge about the grammatical rules and structural points of the language, but since their command of reading comprehension and vocabulary is miserably weak, they are not able to show off and that's because they have put all their eggs in the basket of grammar. This makes reading comprehension and the study of vocabulary at the heart of language teaching and learning.

\subsection{Research Question of the Study}

This study attempts to answer the following question:

Does practicing domestic vs. foreign newspaper have any effect on Iranian Intermediate EFL Learners' reading comprehension ability?

\subsection{Hypothesis of the Study}

Based on the above mentioned research question, the following hypothesis was formulated:

HO: practicing domestic vs. foreign newspaper does not have any effect on Iranian Intermediate EFL Learners' reading comprehension ability.

\section{Review of the Literature}

Do students fully understand what they are reading? Are they able to express verbally what they have read? Professional teachers need to guide students to become independent and effective in 
our fast-paced, fast-growing society. To do this, we need to start with a basic skill that is used throughout life and that skill is reading comprehension.

Reading comprehension is the process of making meaning from text. The goal, therefore, is to gain an overall understanding of what is described in the text rather than to obtain meaning from isolated words or sentences. There are two classes of mental models: a text-based model, which is a mental representation of the propositions of the text and a situation model consisting of what the text is perceived to be about (Kintsch, 1998).

Hedge (2003) states that any reading component of an English language course may include a set of learning goals for

* the ability to read a wide range of texts in English. This is the long-range goal most teachers seek to develop through independent readers outside EFL/ESL classroom,

* building a knowledge of language which will facilitate reading ability,

* building schematic knowledge,

* the ability to adapt the reading style according to reading purpose (i.e. skimming, scanning),

* developing an awareness of the structure of written texts in English, and

* taking a critical stance to the contents of the texts.

The last goal can be implemented at an advanced level. Students, however, should be kept aware that not all internet content is authentic since there are no "gate keepers" and anyone can post whatever he/she likes in this cipher space. Consequently, students can check the authenticity of the text by looking at the following indicators: whether the article gives the name of the author or no, the date of publication, the aim of the article, etc.

Moorman and Ram (1994) state that although much of the research has been carried out on teaching reading, "yet no theories exist which sufficiently describe and explain how people accomplish the complete task of reading real-world texts" (p. 646). Graesser describes six basic knowledge sources involved with textual comprehension: linguistic, rhetorical, causal, intentional, spatial, and roles, personalities, and objects. The theory, however, lacks a process model for its implementation. Van Dijk and Kintsch proposed their reading model in 1983, but it falls short by being unable to handle creative reading.

Many studies in the field of reading comprehension and reading strategies have emphasized the important role reading strategies play in students' comprehension (Dreyer \& Nel, 2003; Mokhtari \& Reichard, 2002, 2004). Research has also compared proficient readers with novice ones to determine what types of strategies skillful readers use to comprehend the text better (Afflerbach, 2002; Garner, 1994). Reading strategy instruction has been found to be highly beneficial for students of all levels; however, it is reported to be especially helpful for low-achieving learners or less-skilled readers to comprehend the text more effectively (Stahl, 2004). 
Reading instruction in which students are typically asked to activate their background knowledge about the topic of the text, review the vocabulary, read the text silently, and answer comprehension questions does not help students become strategic readers (Chamot \& O’Malley, 1996). Many students cannot figure out how to read efficiently if someone does not teach them; thus, they may experience difficulties in understanding what they are reading (Jimenez, Garcia, \& Pearson, 1996).

Therefore, teachers should help their students become skillful and self-regulated readers. This can be achieved by giving them explanations about comprehension strategies, their usefulness, and the way students can use them in the process of reading comprehension (Palincsar \& Brown, 1984). Students' needs, learning styles, and individual preferences should also be considered in strategy instruction to help them use the strategies more flexibly (Pressley, 2002). Explicit reading strategy instruction is beneficial for both learners and teachers because it promotes learners' autonomy and helps teachers motivate their students to actively participate in the process of learning and, thus, increases learning efficiency (Janzen \& Stoller, 1998).

Media are important because we get to know the world through using them; we understand the world and try to change it. UNESCO declaration on Media shows this importance. We live in a world where media are omnipresent. An increasing number of people send a great deal of time watching television, reading newspapers and magazines, playing records and listening to the radio. The school and the family share the responsibility of preparing the young person living in a world of powerful images worlds and sounds.

Mass media in general and newspapers in particular have also received the attention of many critical discourse analysis practitioners to resist the power of newspapers in manipulating and influencing people's ideas in a way that is in favor of the elite of the society. CDA is concerned with discourse in forming and being formed by social political practices (Fairclough, 2001) and aims to raise the readers' consciousness of the power of language in changing the events and influencing the readers' views.

\section{Methodology}

\subsection{The Design of the Study}

This study was an attempt to investigate the effect of practicing domestic vs. foreign newspaper on Iranian intermediate EFL learners' reading comprehension ability. The researcher used the quasi-experimental research design. In this research, out of 100 participants, 45 Iranian intermediate learners were selected via administering an OPT test. The participants of this study were selected via administering an OPT test with the criteria of at least 1 standard deviation below and above the mean of the OPT. The participants were divided into three groups of $15(\mathrm{~N}=15)$ : two experimental groups and a control group. A pre-test of reading comprehension was administered to the three groups and then, the first experimental group was treated by teaching reading comprehension plus domestic newspaper; the second experimental group was treated by teaching reading comprehension plus foreign newspaper and the control group was treated by a 
placebo (No treatment, but teaching reading comprehension). Finally, a posttest of reading comprehension was administered to three groups.

\subsection{Participants}

In this research, out of 100 participants, 45 Iranian intermediate learners were chosen through administering an OPT test. These forty five students participated in this study. They were studying in three intermediate classes in Ramsar, a small city in Iran, in the academic year 2016-2017. The participants were all female and ranged in age from 17 to 19.

\subsection{Data Collection Instruments}

45 Iranian Intermediate EFL learners were selected via administering an OPT test with the criteria of at least 1 standard deviation below and above the mean of the OPT. The OPT consists of reading sections. Reading section of "Reading Practice Test" was used as the OPT. The reading section consists of 19 items. It takes approximately 25 minutes to complete the reading test and test-takers are asked to choose the correct answer. In most cases, the students are to choose the one that best expresses the idea, makes the statement appropriate for standard written English. Test-takers are asked to read these questions. For each question, the students are to choose the alternative they consider best and fill in the corresponding oval on their answer document.

In order to gather the required data, the parts of the reading section of SELECT READINGSIntermediate by Linda Lee and Erik Gundersen 2001 and the parts of Reading \& Vocabulary for TOEFL (Intermediate Level) 2005 were used as the pre-test and the post-test. After administering the OPT, the participants were divided into three groups of $15(\mathrm{~N}=15)$ : two experimental groups and a control group. After assigning the participants to the two experimental groups and a control group, a pre-test of reading comprehension was administered to the three groups and then, the first experimental group was treated by teaching reading comprehension plus domestic newspaper; the second experimental group was treated by teaching reading comprehension plus foreign newspaper and the control group was treated by a placebo (No treatment, but teaching reading comprehension). Finally, a post-test of reading comprehension was administered to both groups.

Pre-post test assesses examinees' ability for reading comprehension. Pre-post test contains several passages. Pre-post test English test is a 22-question, 45-minute test that measures learners' reading comprehension ability. The test consists of multiple-choice test questions.

- Some questions refer to underlined portions of the passage and offer several alternatives to the underlined portion. You decide which choice is most appropriate in the context of the passage.

Different passage types are used to provide a variety of rhetorical situations. Passages are chosen not only for their appropriateness in assessing writing skills but also to reflect students' interests and experiences. Spelling, vocabulary, and rote recall of grammar rules are not tested. 


\subsection{Method of Analyzing Data}

The data obtained from testing the hypothesis of the study were analyzed via calculating One-way ANOVA among the post-test scores and Paired-Sample T-test between practicing domestic and foreign newspaper on reading comprehension ability of groups. The data were entered and analyzed using the SPSS version 22 as the statistical analysis software. First, the researcher entered the data. During the data entry phase, the researcher gave data coding to some variables. Next, an internal consistency was calculated as the measure of the reliability of the instrument (the scale). It should be mentioned that One-way ANOVA among the post-test scores and Paired-Sample Ttest between the pre-test and post-test scores of each group were also used in this study.

\section{Data Analysis and Findings}

\subsection{Descriptive Analysis of the Data}

Table 1 shows the descriptive results of the first experimental $(\mathrm{F})$ group of the study. As indicated in Table 1, the number of participants has been 15 in each experiment $(\mathrm{N}=15) ;(\mathrm{N}=15)$, and there has been no missing value (Missing Value=0.00) which means that all selected participants participated in the experiments of the study. The mean for Pre-test Foreign (F) newspaper scores was shown to be 16.0667 as compared to the mean for Post-test Foreign (F) newspaper scores which was 17.8667. As for the standard deviation obtained for Pre-test Foreign newspaper group, there seems to be more variability among the Pre-test Foreign newspaper score than the scores in the Post-test F.

Table 1. Descriptive results of the first experimental (F) group of the study

\begin{tabular}{cccccc}
\hline & & & Std. & \\
& & Mean & $\mathrm{N}$ & Deviation & Std. Error Mean \\
\hline Pair 1 & Pretest F & 16.0667 & 15 & 0.79881 & 0.20625 \\
& Posttest F & 17.8667 & 15 & 1.12546 & 0.29059 \\
\hline
\end{tabular}

Table 2 shows the descriptive results of the second experimental (D) group of the study. As indicated in Table 2, the number of participants has been 15 in each experiments $(\mathrm{N}=15) ;(\mathrm{N}=15)$, and there has been no missing value (Missing Value=0.00) which means that all selected participants participated in the experiments of the study. The mean for Pre-test Domestic (D) newspaper scores was shown to be 14.1333 as compared to the mean for Post-test Domestic (D) newspaper scores which was 15.0000. As for the standard deviation obtained for Pre-test Domestic newspaper group, there seems to be more variability among the Pre-test Domestic newspaper score than the scores in the Post-test D. 
Table 2. Descriptive results of the second experimental (D) group of the study

\begin{tabular}{|c|c|c|c|c|c|}
\hline & & Mean & $\mathrm{N}$ & $\begin{array}{c}\text { Std. } \\
\text { Deviation }\end{array}$ & Std. Error Mean \\
\hline \multirow[t]{2}{*}{ Pair 2} & Pretest D & 14.1333 & 15 & 0.83381 & 0.21529 \\
\hline & Posttest D & 15.0000 & 15 & 1.92582 & 0.23905 \\
\hline
\end{tabular}

Table 3 shows the Descriptive results of the control (P) group of the study. As indicated in Table 3 , the number of participants has been 15 in each experiments $(\mathrm{N}=15) ;(\mathrm{N}=15)$, and there has been no missing value (Missing Value $=0.00$ ) which means that all selected participants participated in the experiments of the study. The mean for Pre-test Placebo $(\mathrm{P})$ newspaper scores was shown to be 12.8000 as compared to the mean for Post-test Placebo (P) newspaper scores which was 12.7333. As for the standard deviation obtained for Pre-test Placebo newspaper group, there seems to be more variability among the Pre-test Placebo newspaper score than the scores in the Post-test P.

Table 3. Descriptive results of the control (P) group of the study

\begin{tabular}{|c|c|c|c|c|c|}
\hline & & Mean & $\mathrm{N}$ & $\begin{array}{c}\text { Std. } \\
\text { Deviation }\end{array}$ & Std. Error Mean \\
\hline \multirow[t]{2}{*}{ Pair 3} & Pretest P & 12.8000 & 15 & 2.65115 & 0.68452 \\
\hline & Posttest P & 12.7333 & 15 & 1.75119 & 0.45216 \\
\hline
\end{tabular}

\subsection{The Inferential Analysis of the Data}

This section focuses on the inferential analysis of the obtained data of this study. Such analysis was done using the SPSS (Statistical Package for Social science) to determine whether there was any statistically significant difference between the scores of the groups. The results are presented in Table 4. 
Table 4. One-Way ANOVA results of the study

\begin{tabular}{cccccc}
\hline & Sum of Squares & Df & Mean Square & F & Sig. \\
\hline Between Groups & 198.533 & 2 & 99.267 & $\mathbf{5 7 . 3 7 4}$ & $\mathbf{0 . 0 0 0}$ \\
Within Groups & 72.667 & 42 & 1.730 & & \\
Total & 271.200 & 44 & & & \\
\hline
\end{tabular}

Table 4 shows One-Way ANOVA results of the study. As indicated in Table 4, there was no significant difference because level of significance was below 0.05. F was $\mathbf{5 7 . 3 7 4}$ in the between groups. So, F > 1; that is, $57.374>1$. And level of significance was calculated as to be 0.00 which has been used in interpreting the data for the rejection or support of the first hypothesis of the study in the next section. The level of significance for two-tailed test was zero; So, Sig. $>1$; that is 0.000 $<0.05$. In the between groups, Mean Square was 99.267. In the within groups, Mean Square was 1.730. And degree of freedom was 2 for the between groups and for the within groups was 42 .

In order to investigate students' progress within groups from pre-test to post-test, paired-samples were run. The results are shown in Table 5.

Table 5. Paired Sample results of the study

\begin{tabular}{cccccc}
\hline & & Observed t & Critical t & Df & Sig. (2-tailed) \\
\hline Pair 1 & Pretest F - Posttest F & 12.435 & 2.145 & 14 & 0.000 \\
Pair 2 & Pretest D - Posttest D & 9.539 & 2.145 & 14 & 0.000 \\
Pair 3 & Pretest P - Posttest P & 0.250 & 2.145 & 14 & 0.008 \\
\hline
\end{tabular}

As indicated in Table 5, the level of significance (df) for two-tailed test was 14. In the pair 1 (Pretest F - Post-test F), Observed t was 12.435 and Critical t was 2.145. So, Observed t $>$ Critical t; that is, $12.435>2.145$. And level of significance for two-tailed test was zero; that is, Sig. $<0.05$; that is $0.000<0.05$. When Observed $t>$ Critical $t$; the observed $t$ was higher than the critical $t$ and 
high enough to reject the null hypothesis of this study; that is, the hypothesis is rejected. Pair 1 (Pre-test F - Post-test F) had a progress in the reading comprehension of post-test.

And in the pair 2 (Pre-test D - Post-test D), Observed t was 9.539 and Critical t was 2.145. So, Observed $t>$ Critical $t$; that is, $9.539>2.145$. And level of significance for two-tailed test was zero; that is, Sig. $<0.05$; that is $0.000<0.05$. Pair 2 (Pre-test D - Post-test D) had a progress in the reading comprehension of posttest, but it was less than pair 1 . Thus, the observed $t$ was higher than the critical $t$ and high enough to reject the null hypothesis of this study.

And in the pair 3 (Pre-test $\mathrm{P}$ - Post-test P), Observed t was 0.250 and Critical t was 2.145. So, Observed $\mathrm{t}<$ Critical $\mathrm{t}$; that is, $0.250<2.145$. And level of significance for two-tailed test was 0.008 ; that is, Sig. $<0.05$; that is $0.008<0.05$, it shows that there was no difference between Pretest $\mathrm{P}$ and Post-test $\mathrm{P}(\mathrm{P} \rightarrow$ Placebo). Based on these results, the null hypothesis of this study was rejected. Finally, the level of significance was calculated as to be 0.008 ; that is, there was no difference between Pre-test $\mathrm{P}$ and Post-test $\mathrm{P}$, which has been used in interpreting the data for the rejection or support of the first hypothesis of the study in the next section. But, in pair 1 and pair 2 , progresses obtained; that is, there were differences.

\subsection{Results of Hypotheses testing}

In this section, the results of testing the hypothesis of the study have been presented and elaborated. In order to give a detailed analysis, attempts were made to take advantage of the results of the study as evidence to determine the rejection or support of the hypothesis was justified by explaining the consequences of such rejection or support, i.e. what would happen if the hypothesis of the current study was rejected or supported. Before analyzing the hypothesis, it is repeated below:

Practicing domestic vs. foreign newspaper does not have any effect on Iranian Intermediate EFL learners' reading comprehension ability.

The hypothesis of the study which targeted the effect of practicing domestic vs. foreign newspaper doesn't have any effect on Iranian Intermediate EFL learners' reading comprehension ability was rejected. Evidence from various sources of data could help to verify the rejection. The results of the observed t of the study (see Table 5) could be employed to confirm this analysis, accordingly, the observed $t$ determined on the basis of considering the 2-tailed significance level of 0.05 was $12.435(\mathrm{t}=12.435)$. (observed $\mathrm{t}>$ critical $\mathrm{t} \rightarrow 12.435>2.145$ ). Thus, the observed $\mathrm{t}$ was higher than the critical $t$ and high enough to reject the null hypothesis of this study.

The second evidence to verify the rejection of the hypothesis was the value of the level of significance calculated by the SPSS to be 0.008 (significance=0.008) since this value was lower than 0.05 (based on the SPSS regulation), the difference between the means of practicing domestic vs. foreign newspaper of the study could not be by chance, and thus, the rejection of the hypothesis of the study indicated that practicing domestic vs. foreign newspaper on Iranian Intermediate EFL 
learners' reading comprehension ability would enhance reading comprehension ability of the participants in this study.

\section{General Discussion}

This study produced results which corroborate the findings of the previous work in this field. These findings are in agreement with Fenholt's (1985) findings which newspapers improve reading comprehension ability through enhanced attention. Fenholt offers numerous activities that are based upon the use of newspapers as a learning resource to enhance reading and life skills of the students. There are different purposes and ways for using newspapers in language classroom. They may be used for the culture they transmit. The more widely students read, the greater their understanding of this cultural meaning will be. At the same time, newspapers provide a natural source of many of the varieties of Written English that become very important to students, and valuable for language study as the students progress.

These findings also accord with Paul Sanderson's (2002) findings, which indicated that students think newspapers are more interesting than books. Most newspapers are linguistically up-to-date and provide valuable linguistic data. They may be used for the wide variety of text types and language styles, not often found in textbooks. Paul Sanderson states that "People learn through reading, and reading about interesting new things in one's interest subject, undoubtedly helps motivation."

Paul Sanderson (2002) stated that a very important thing that enhances success in using newspapers in the classroom is the careful design of tasks. 'Grade the task - not the material' is a well-known maxim in language teaching.' Some newspapers are easy to read, easy to use. The committed teachers can design exercises to develop reading comprehension. Newspapers can be used as a very effective teaching tool.

The use of practicing domestic vs. foreign newspaper also may be of great help in learners' improvement in reading comprehension. Chatwirote (2003 cited in Thangyon \& Chiramanee, 2011) suggested that the teachers could provide reading promoting activities, such as the activities that interest the learners. The activities should contain the reading objectives that suit the learners' and teachers' interest.

The results of this study are in line with previous studies conducted by Monda, Vail, and Koorland (1988). Regarding the results of the post-test, which showed that practicing newspapers may have better effect on improvement in reading comprehension, the present study is compatible with the study conducted by Howden (1990) who stated that the "Palm Beach Post" in Florida offered a workplace literacy program with six classes in three different programs viz Adult Basic Education, English as a Second Language and High school Equivalency in preparation of a Diploma Program. Learning Disabled (LD) students can also be benefited by using newspapers in the classroom.

Many practitioners (Hess, 1987; Salas-Isnardi, n.d.; Toben, 1987) have compiled detailed and level-appropriate lists of classroom activities for using the newspaper as text. Lindsay Clandfield 
and Duncan Foord (2006) stated that newspapers are much more current than course-books, they make an excellent springboard for lessons, and they feature different types of language (narratives, stories, letters, advertising, reports, etc.). Monda, Vail and Koorland highlighted that the newspapers can be very potentials for the LD (Learning Disabled) institutions to build an individualized institutional program.

The results of the present study are in line with Vilma Tafani (2009) too. Vilma Tafani analyzes the importance of using mass media in the classroom and finds the ways of using printing and audio-visual media. Vilma Tafani reports that students practicing newspaper will outperform the traditional group practicing only a book-based, because students in such a class will have more opportunities to make referential connections between active and up-to-date representation than in traditional presentation. Media Education is important because it develops students' creative powers for those images, words, and sounds that come to the students from various Media.

Vilma Tafani (2009) reports that newspapers are easy to be brought in the class in different subjects and courses, especially in geography, history, literature, language classes, etc. There are different purposes and ways for using newspapers in language classroom. They may be used for the culture they transmit. The more widely students read, the greater their understanding of this cultural meaning will be. They may also be used for reflecting changes in the language as well, and in doing so, helping students and teachers keep up pace with such changes. Most newspapers are linguistically up-to-date and provide valuable linguistic data. They may be used for the wide variety of text types and language styles, not often found in textbooks. At the same time, newspapers provide a natural source of many of the varieties of written English that become very important to students, and valuable for language study as the students progress. So, they may be used as supplementary material and examples in text analysis, academic writing, stylistics, semantics, etc. while analyzing different types of texts.

The variety of subjects and topics makes newspapers interesting and motivating for the students to work with. Newspapers report real-life events, and this arouses students' curiosity. Newspaperbased activities in the classroom may engage students in enjoyable activities and encourage their further reading. Newspapers are an invaluable source of authentic materials. The more students read, the more they want to explore. Therefore, newspapers help in making EFL classrooms highly interactive by using practicing newspapers. This is consistent with the results of other studies such as Vilma Tafani (2009), Kenji Kitao (1995), and Lindsay Clandfield and Duncan Foord (2006).

\section{Implications of the Study}

The findings of this study suggest that the use of practicing domestic vs. foreign newspaper for helping students and their encouragement for learning better influences on reading comprehension ability. According to the results of this study, practicing domestic vs. foreign newspaper had great impact on Iranian Intermediate EFL learners' reading comprehension ability. After the writer analyzed the result of action research which had been conducted to enhance the reading comprehension ability of Intermediate EFL learners, it could be seen that the use of printed mass 
media in teaching reading comprehension can enhance students' reading comprehension ability. From the observation, the researcher found that during the action, the students have shown their improvement such as they are able to comprehend the text well, the situation of the teaching and learning process becomes more joyful and interesting, the students also weren't reluctant to open their dictionary, and all of the students were involved in the teaching and learning process.

Based on the conclusion of all of the data in the research, there is enhancement of students' reading comprehension ability taught by using texts from newspapers. The writer can imply that the use of printed mass media in teaching reading can be suitable teaching materials to improve students' achievement and enhance students' motivation. It means that the use of texts from newspapers can be developed in the process of teaching and learning language. This is proven to be an effective material resource to improve students' reading ability. There are some advantages of using texts from newspapers for the students which include: (1) texts from newspapers can create a motivating situation so that they don't feel bored in learning activity, they have responsibility to do their task without any hesitation, (2) texts from newspapers have many choices to choose as the reading materials, and (3) texts from newspapers are interesting since it is offered painted and colored materials.

\section{Suggestions for further Research}

The writer would like to give some suggestions which hopefully these suggestions will be useful. English as a second language seems difficult to learn if there is no will and motivation to learn it. The students who are taught by using texts from domestic vs. foreign newspapers should be aware of the importance of reading to get some information they need. They should not judge that reading as a boring activity. The teacher can use the texts from printed mass media especially newspapers to improve students' ability in reading comprehension. The use of newspapers which are close with students' daily life and offer motivating material can motivate the students to learn. The subjects of this research were at intermediate learners of English institute. Other research projects can also be carried out regarding other level of the learners such as elementary or advance learners, etc.

The participants of this research studied in English institute. Other researchers can be conducted at school or university setting. The age range of participants in this study was from 17 to 19 years old and the participants were all female. Other researches can be carried with other age ranges such as children or adults and it can be all men. Maybe for future research it is beneficial to study the effect of domestic vs. foreign newspapers on the other skills of language e.g. speaking, listening, writing, or on the other knowledge of language e.g. adverb, preposition, vocabulary, etc.

\section{Conclusion}

This study attempted to determine the effect of practicing domestic vs. foreign newspaper on Iranian Intermediate EFL learners' reading comprehension ability. The study's hypothesis i.e "practicing domestic vs. foreign newspaper does not have any effect on Iranian Intermediate EFL learners' reading comprehension ability" was rejected. It indicates that practicing domestic vs. foreign 
newspaper has a positive effect on Iranian Intermediate EFL learners' reading comprehension ability. These findings have a lot of implications for different stakeholders in educational settings. In line with the results of this study, one of the most important responsibilities of teachers, materials developers, and course designers is providing opportunities for a more effective and different uses of practicing English newspapers for a better teaching and learning of different skills and components of language.

The research problems that may arise from this study are questioning on how good is the reading ability of Iranian Intermediate EFL learners, what is the problem faced by the teacher in improving Iranian Intermediate EFL learners' reading comprehension ability, whether domestic and foreign newspapers are able to affect on Iranian Intermediate EFL learners' reading comprehension ability by practicing domestic vs. foreign newspaper on Iranian Intermediate EFL learners' reading comprehension ability, whether the content of domestic and foreign newspapers raises the learners' interest in reading.

Since there are many problems that arise in this study, the study limits the problems on improving Iranian Intermediate EFL learners' reading ability by using foreign and domestic newspapers. Here the study limits the use of printed mass media only newspapers. The study was limited to just reading skill, so the other components of language remained untouched. The sample size was another limitation in the present study which confined to one specific class with small sample size, so great caution should be exercised generalizing the results to other situations.

The age of the participants in this study ranged from 17 to18 years old. The contribution of other learners with a different age range could possibly result in different outcomes. Another delimitation of this study was that all the participants were intermediate students in just one language institute i.e. Simin English Language Institute in Ramsar, Iran. Thus, the generalizability of the findings of this study must be treated more cautiously as a small sample of participants was included in the study. The participants were all selected from intermediate level; therefore, the results can't be generalized to the learners in other proficiency levels. The researcher hopes that this study will give benefits for the betterment of English teaching and learning process.

\section{References}

Adams, M. J. (1990). Beginning to read: Thinking and learning about print. Cambridge, MA: MIT Press.

Afflerbach, P. (2002). Teaching reading self-assessment strategies. In C. Block \& M. Pressley (Eds.), Comprehension instruction: Research-based best practices (pp. 96-111). New York: Guilford Press.

Anderson, N. (1999). Exploring second language reading: Issues and strategies. Boston, MA: Heinle and Heinle publisher.

Chamot, A., \& O’Malley, M. (1996). The academic cognitive language learning approach: A model for linguistically diverse classrooms. The Elementary School Journal, 96(3), 259-273. https://doi.org/10.1086/461827

Chiramanee, T., \& Thangyon, P. (2011). The effects of pre-reading activities on reading comprehension ability. Retrieved March 1, 2013, from http:// sv.libarts.psu.ac.th/conference5/proceedings/Proceedings3/.../003 
Clandfield, L., \& Foord, D. (2006). Teaching English overseas: Using newspapers in the classroom. http://www.transitionsabroad.com/publications/magazine/0601/teaching_english_oerseas_using_newspapers_cl assroom.shtm

Davies, F. (1995). Introducing Reading. England: Penguin Book.

Dreyer, C., \& Nel, C. (2003). Teaching reading strategies and reading comprehension within a technology-enhanced learning environment. System, 31(30), 349-365. https://doi.org/10.1016/S0346-251X(03)00047-2

Emery, E. (1968). Introduction to mass communication. New York: Dodd, Mead and Company, Inc.

Fairclough, N. (2001). Critical discourse analysis as method in social scientific research. In R. Wodak, \& M. Meyer (Eds.), Methods of critical discourse analysis (pp. 121-129). London: SAGE.

Fenholt, J. (1985). The newspaper: Your key to better living. Using the newspaper in adult education classes. American Newspaper Publishers Association (ANPA) Foundation, Washington, DC.

Garner, R. (1994). Metacognition and executive control. In R. Ruddell, M. Ruddell, \& H. Singer (Eds.), Theoretical models and processes of reading (4th ed.; pp. 715-732). Newark, DE: International Reading Association.

Goodman, K. S. (1967). Reading a psycholinguistic. Journal of the Real Specialist, 6(4), 126-135. https://doi.org/10.1080/19388076709556976

Grabe, W. (1991). Current developments in second language reading research. TESOL Quarterly, 25(3), 375-406. doi: 10.2307/3586977 http://www.jstor.org/stable/3586977

Grabe, W. (1997). Discourse analysis and reading instruction. In T. Miller (Ed), Functional approaches to written text: Classroom applications (pp. 2-15). Washington, DC: United States Information Agency. Retrieved from: eric.ed.gov/?id=ED417422.

Hedge, T. (2003). Teaching \& learning in the language classroom. UK: OUP.

Hess, N. (1987). Newspapers in the English classroom: Stressing sociolinguistic communicative competence in an authentic framework. English Teachers Journal, 35, 70-71.

Howden, G. (1990). Workplace literacy. Paper presented at the ANPA Foundation Literacy Conference. [ED 323 364].

Janzen, J., \& Stoller, F. (1998). Integrating strategic reading in L2 instruction. Reading in a Foreign Language, 12(1), 251-269. https://eric.ed.gov/?id=EJ583987

Jimenez, R. T., Garcia, G. E., \& Pearson, D. P. (1996). The reading strategies of bilingual Latino students who are successful English readers: Opportunities and obstacles. Reading Research Quarterly, 31(1), 90-112. https://doi.org/10.1598/RRQ.31.1.5

Kintsch, W. (1998). Comprehension: A paradigm for cognition. New York: CPU.

Kitao, K. (1995). Teaching English through newspapers. English Literary Society of Doshisha University.

Mokhtari, K., \& Reichard, C. (2002). Assessing students' metacognitive awareness of reading strategies. Journal of Educational Psychology, 94(2), 249-259. https://eric.ed.gov/?id=EJ648499

Mokhtari, K., \& Reichard, C. (2004). Investigating the strategic reading processes of first and second language readers in two different cultural contexts. System, 32(3), 379-394. https://doi.org/10.1016/j.system.2004.04.005

Monda, L. E., Vail, C. O., \& Koorland, M. A. (1988). Newspapers and LD students. Journal of Reading, 31(7), 678679. 
Moorman, K., \& Ram, A. (1994). Integrating creativity and reading: A functional approach. Proceedings of the Sixteenth Annual Conference of the Cognitive Science Society: Cognitive Science Program. Georgia Institute of Technology. Hillsdale, NJ: Lawrence Erlbaum Associates.

National Reading Panel. (2000). Report of the National Reading Panel: Teaching children to read. Washington, DC: U.S. Department of Health and Human Services.

Palincsar, A. S., \& Brown, A. L. (1984). Reciprocal teaching of comprehension fostering and comprehensionmonitoring activities. Cognition and Instruction, 1(2), 117-175. https://doi.org/10.1207/s1532690xci0102_1

Panah. E. (2009). Strategies for learning and Remembering of Vocabulary Items by Learners. A Thesis Submitted in Partial Fulfilment of the Requirement Iranian EFL for M.A Degree.

Pressley. G. M. (2002). Reading instruction that works: The case for balanced teaching (2nd ed.). New York: The Guildford Press.

Salas-Isnardi, F. (n.d.). Some ideas for the use of a newspaper in the E.L.A.P. class. Unpublished manuscript.

Salinger, T. (2003). Helping older, struggling readers. Previewing School Failure, 47(2), 79-87. https://doi.org/10.1080/10459880309604434

Sanderson, P. (2002). Using newspapers in the classroom. CUP. https://www.developingteachers.com/books/review_unitc.htm.

Stahl, K. A. D. (2004). Proof, practice, and promise: Comprehension strategy instruction in the primary grades. The Reading Teacher, 57(7), 598-609. https://steinhardt.nyu.edu/scmsAdmin/uploads/006/713/StahlpppRT.pdf

Tafani, V. (2009). Teaching English through mass media. Acta Didactica Napocensia, 2(1), 81-95. https://eric.ed.gov/?id=EJ1052325

Toben, M. (1987). Using the newspaper in the classroom: A check list for intermediate and advanced classes. English Teachers Journal, 35, 79-82.

Varzegar, M. (1995). The discoursal aspects of reading comprehension. Pazhuhesh, 11, 109-120.

Wallace, C. (1992). Reading. Oxford: Oxford University Press.

Williams, E. (1996). Reading in the language classroom. UK: Hert Fortshire Phoenix, elt 